\title{
Publications on personality disorders in Brazilian journals: a narrative review
}

\author{
Lucas de Francisco Carvalho ${ }^{1}$ (D) Gabriel Vitor Acioly Gomes (D) \\ Universidade São Francisco, Campinas-SP, Brasil \\ Ednelson da Silva (1D \\ Universidade Federal de São Paulo - Baixada Santista, Santos-SP, Brasil
}

\section{ABSTRACT}

Despite the prevalence of personality disorders (PD) and their association with several harmful health outcomes, previous reports found a low number of studies on PDs conducted in Brazil. We conducted a narrative review to investigate the current state of research in Brazil focusing on PDs. The search was performed in BVS-Psi, PePSIC, and Google Scholar databases. We focused on papers published in Brazilian journals as a criterion to select studies conducted in Brazil and/or coordinated by Brazilian researchers. A total of 177 papers were included. Approximately $60 \%$ of papers were empirical studies, although only $47.17 \%$ of them had clinical samples. Borderline and Antisocial were the most recurrently investigated PDs. Two scales were usually administered, IDCP and PID-5. SCID-II was administered in less than 5\% of empirical studies. We proposed an agenda for research on PDs in Brazil, including guidelines and directions eminently urgent to the studies to be conducted in Brazil.

Keywords: psychiatric disorders; literature review; personality assessment; personality traits.

RESUMO - Publicações sobre Transtornos da Personalidade em Revistas Brasileiras: Uma Revisão Narrativa

Apesar da prevalência dos transtornos da personalidade (TP) e a associação com diversas consequências prejudiciais, estudos prévios encontraram um número escasso de pesquisas conduzidas no Brasil. Nós conduzimos uma revisão narrativa para investigar o estado atual de pesquisas no Brasil com foco em TP. A busca foi realizada nas bases BVS-Psi, PePSIC e Google Acadêmico. Nós focamos em artigos publicados em periódicos brasileiros como critério para seleção de estudos conduzidos no Brasil e/ou coordenados por pesquisadores brasileiros. No total, 177 artigos foram selecionados. Aproximadamente 60\% eram estudos empíricos, embora apenas $47.17 \%$ destes, incluíram amostras clínicas. Os TPs mais investigados foram Borderline e Antissocial. As duas escalas mais aplicadas foram o IDCP e o PID-5. A SCID-II foi aplicada em menos de 5\% dos estudos empíricos. Nós propomos uma agenda para pesquisas sobre TP no Brasil, incluindo diretrizes e direções urgentes para estudos a serem conduzidos no Brasil.

Palavras-chave: transtornos psiquiátricos; revisão de literatura; avaliação da personalidade; traços de personalidade.

RESUMEN - Publicaciones sobre trastornos de personalidad en revistas brasileñas: una revisión narrativa

A pesar de la prevalencia de los trastornos de la personalidad (TP) y su asociación con varias consecuencias nocivas, estudios previos han encontrado un escaso número de estudios realizados en Brasil. Se realizó una revisión narrativa para pesquisar el estado actual de la investigación en Brasil con un enfoque en el TP. La búsqueda se realizó en las bases de datos BVS-Psi, PePSIC, y Google Scholar. Priorizando artículos publicados en revistas brasileñas como criterio de selección de los estudios realizados en Brasil y/o coordinados por investigadores brasileños. En total, 177 artículos fueron seleccionados. Aproximadamente el $60 \%$ fueron estudios empíricos, aunque solo el 47.17\% de estos incluyeron muestras clínicas. Los TP más investigados fueron Borderline y Antisocial. Las dos escalas más aplicadas fueron el IDCP y el PID-5. La SCID-I se aplicó en menos del 5\% de los estudios empíricos. Se propuso una agenda para la investigación sobre TP en Brasil, incluyendo las directrices y orientaciones eminentemente urgentes a los estudios que se llevarán a cabo.

Palabras clave: trastornos psiquiátricos; revisión de literatura; evaluación de la personalidad; rasgos de personalidad.

Systematic reviews (Steel et al., 2014; Wittchen et al., 2011) have found approximately $30 \%$ to $40 \%$ of the world population suffering from mental disorders. Personality disorders (PDs) represent mental disorders composed mainly of specific pathological traits (Kotov et al., 2017). These disorders are persistent and inflexible pathological patterns, including internal distress and atypical behaviors, which have substantial impairments in the individual's several areas of life (American Psychological Association [APA], 2013). Evidence suggests that PDs are undertreated worldwidely (Paris, 2015), although related to several negative outcomes. In Brazil, PDs seem to be less investigated than other mental disorders (Carvalho et al., 2010). This study mapped methodological aspects 
and potential gaps of PD studies published on Brazilian scientific journals. Focusing on these disorders, we conducted a narrative review investigating the country's current state of research. We opted for conducting a narrative review due to the nature of the research problem, focused on Brazil, which would be an inadequate restriction for a systematic review (Knipschild, 1994; Littell et al., 2008).

\section{Theoretical background}

PDs are extreme pathological variants of healthy personality patterns, resulting from predisposing temperaments and stressful circumstances (Oldham, 2017). Impairments in self and interpersonal relationships are present in people with PDs, involving distress in several life areas (APA, 2013; Skodol, 2012). PDs have prevalence from $5 \%$ to $13 \%$ in community samples (Germans et al., 2012; Samuels, 2011), and even higher indexes in North and South America (Huang et al., 2009). In Brazil, an epidemiologic study was conducted in the São Paulo megacity with the general population, finding around $7 \%$ of prevalence estimates (Santana et al., 2018).

A previous systematic review (Dixon-Gordon et al., 2015) found numerous harmful health outcomes associated with PDs (e.g., sleep disturbances and other chronic health conditions). For instance, negative outcomes from PDs include obesity (Gerlach et al., 2016), decreased quality of life (Cramer et al., 2006), and selfharm and suicide attempts (Krysinska et al., 2006; Yen et al., 2003).

Although PDs present substantial prevalence estimates and several harmful negative outcomes, Carvalho et al. (2010) found a low number of studies on PDs conducted in Brazil, which corroborates the international literature suggesting PDs are undertreated in mental health clinic (e.g., Paris, 2015). To map potential gaps and bring to knowledge details on studies from a specific field (e.g., how studies are being directed and designed), literature reviews can be conducted (e.g., Baumeister, \& Leary, 1997). From our knowledge, no literature review has been published focusing on studies conducted in Brazil. This study aimed to investigate the current state of research in Brazil, focusing on personality disorders. Therefore, we accomplished a narrative review. A narrative review is characterized by synthesizing primary studies and exploring heterogeneity descriptively, including systematically extracting, checking, and narratively summarizing information on their methods and results (Petticrew, \& Roberts, 2006). In a narrative review, authors must identify gaps and present suggestions on studies development seeking to deal with potential issues related to the field (Gil, 2008; Marconi, \& Lakatos, 2003).

\section{Methods}

\section{Search strategy}

This study was conducted according to Preferred Reporting Items for Systematic Reviews and MetaAnalyses (PRISMA; Moher et al., 2015) guidelines. We prioritize data bases including Brazilian journals: Biblioteca Virtual de Saúde - Psicologia Brasil (BVS-Psi Brasil), Periódicos Eletrônicos em Psicologia (PePSIC), and Google Scholar. We focused on papers published in Brazilian scientific journals as a criterion to select studies conducted in Brazil and/or coordinated by Brazilian researchers. The following search strategies were used for BVS-Psi Brasil and PePSIC: "Personality disorders OR Personality traits OR Personality processes OR Personality disorders", and "(disorder AND personality) OR ((traits OR characteristics) AND (pathological OR disadaptive OR maladaptive OR abnormal) AND (personality))". Specifically, on Google Scholar, the search strategy was: "(disorder ${ }^{\star}$ AND personality $\left.{ }^{\star}\right)$ OR ((trait* OR characteristic ${ }^{\star}$ ) AND (pathological` OR disadapt ${ }^{\star}$ OR maladapt ${ }^{\star}$ OR abnorm ${ }^{\star}$ ) AND (personality $\left.{ }^{\star}\right)$ )". We accomplished the search in English and Portuguese language for databases, but in Google Scholar the English search presented no sensitivity.

\section{Eligibility criteria}

We conducted a screening of each paper's title and abstract selected from the search strategy, checking whether the focuses were clearly on personality disorders. Disagreements were solved by discussion until we reached a consensus. The selected studies from this screening were evaluated according to the criteria outlined in the sequence.

Papers included in the systematic review were those: (a) focused on the personality disorders or pathological traits according to DSM-5 sections 2 or 3 (APA, 2013); (b) theoretical or review studies; (c) empirical studies with adult Brazilian samples (i.e., age $\geq 16$ years - cut-off determined according to studies focusing on adults that included people from 16 years old); (d) published in Brazilian scientific journals. As exclusion criteria, we did not include book reviews or letters to the editor. No study design or date limits were imposed on the search.

\section{Data extraction}

On April/2021 data were extracted using a standardized data extraction method by the authors. Paper management was conducted using a spreadsheet, where the papers' information (i.e., title and abstract) was recorded. Papers selected from the screening stage were downloaded and fully read, independently. Discrepancies were solved by consensus. Reasons for the posteriori exclusion of studies that had been identified as relevant in the initial abstract searches were recorded. 


\section{Results}

\section{Study Selection}

Initially, a total of 1407 papers were found, including a manual search through Google Scholar. In the screening stage, 730 papers were selected after duplicate verification. After reading titles and abstracts, we selected 196 papers. Following the evaluation for the selected papers' eligibility, the inclusion criteria were applied, and we included 177 papers in this study. The flow diagram details this process in Figure 1.

Figure 1

Flow diagram according to PRISMA Group - Moher et al. (2009)

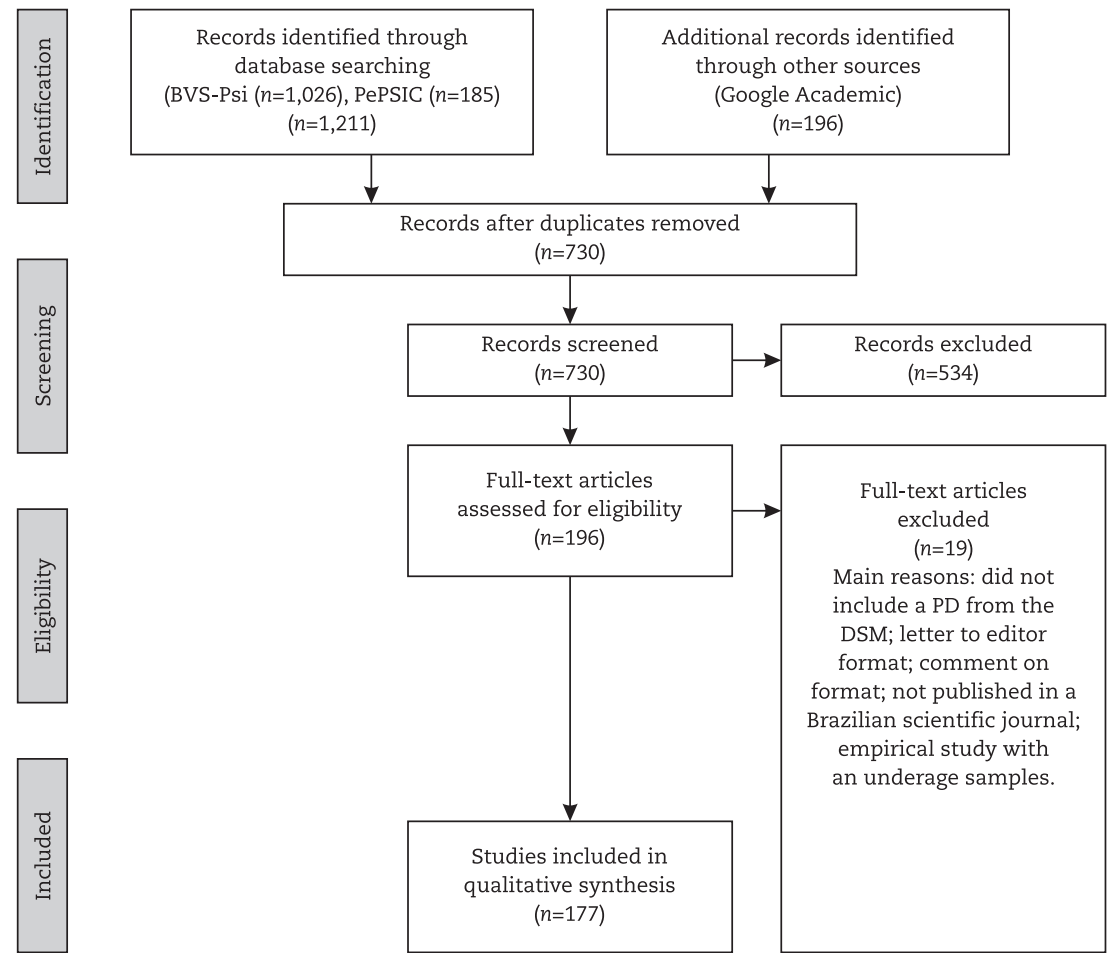

\section{Studies Characteristics}

Regarding the 177 papers included in this review, we observed that the number of authors per publication was between one and $11(M=3.03 ; S D=1.78)$, and most papers were published by two authors (29.38\%). Besides, most of them were written in Portuguese (64.41\%), followed by English (32.77\%), and Spanish $(2.82 \%)$, although an increase of papers in English was observed from 2014 to 2021 (representing 86\% of total papers in English). The majority of the first authors were doctors (42.37\%) or masters $(32.20 \%)$; most of the first authors were from the psychological field $(64.41 \%)$ or medicine (23.73\%); Universidade São Francisco (22.03\%) and Universidade de São Paulo (8.47\%) were the most frequent institutions of the first authors; São Paulo (46.33\%) and Rio Grande do Sul (17.51\%) were the Brazilian states with the majority of publications.
Table 1 presents information on journals of the included papers.

The papers were published in 62 scientific journals. The Brazilian journal of psychiatry (10.17\%), Trends in psychiatry and psychotherapy (8.47\%), Trends in Psychology (7.34\%), Brazilian Journal of Psychiatric - UFRJ (6.78\%), and Archives of Clinical Psychiatric $(5.65 \%)$ were journals with more publications alone. The year of publication ranged from 1985 to 2021, and 2015 was the year with more publications alone (9.60\%). Approximately $60 \%$ of the papers were empirical studies, and more recurrent designs were review and/or theoretical $(37.85 \%)$, and cross-sectional (37.85\%). Moreover, publications before 2010 were mainly reviews, theoretical or case studies; publications from 2010 on were primarily empirical studies, generally focusing on verifying the psychometric properties of assessment tools. 
Table 1

Results on Journals of the Included Papers

\begin{tabular}{|c|c|c|c|}
\hline Categories & Classification & $\begin{array}{c}\text { Papers } \\
(\mathrm{N})\end{array}$ & $\begin{array}{c}\text { Papers } \\
(\%)\end{array}$ \\
\hline \multirow{28}{*}{ Journals } & Brazilian Journal of Psychiatric - ABP & 18 & 10.17 \\
\hline & Trends in psychiatry and psychotherapy & 15 & 8.47 \\
\hline & Trends in Psychology & 13 & 7.34 \\
\hline & Brazilian Journal of Psychiatric - UFRJ & 12 & 6.78 \\
\hline & Archives of Clinical Psychiatric & 10 & 5.65 \\
\hline & Paidéia & 6 & 3.39 \\
\hline & Psicologia: Teoria e Pesquisa & 6 & 3.39 \\
\hline & Avaliação Psicológica & 5 & 2.82 \\
\hline & Brazilian Journal of Behavioral and Cognitive Therapy & 5 & 2.82 \\
\hline & Psychological Studies (Campinas) & 5 & 2.82 \\
\hline & Psychology: Theory and Practice & 5 & 2.82 \\
\hline & Psychology: Research and Review & 4 & 2.26 \\
\hline & Revista Latinoamericana de Psicopatologia Fundamental & 4 & 2.26 \\
\hline & Brazilian Journal of Cognitive Therapies & 3 & 1.69 \\
\hline & Clinical Psychology & 3 & 1.69 \\
\hline & Journal Psychology: Organizations and Work - rPOT & 3 & 1.69 \\
\hline & Psico & 3 & 1.69 \\
\hline & Psico-USF & 3 & 1.69 \\
\hline & Interação em Psicologia & 3 & 1.69 \\
\hline & Psychology: Science and Profession & 3 & 1.69 \\
\hline & Acta Paulista de Enfermagem & 2 & 1.13 \\
\hline & Aletheia & 2 & 1.13 \\
\hline & Arquivos Brasileiros de Psicologia & 2 & 1.13 \\
\hline & Phenomenological Studies - Journal of the Gestalt Approach & 2 & 1.13 \\
\hline & Revista Mudanças & 2 & 1.13 \\
\hline & Studies of Psychology & 2 & 1.13 \\
\hline & Revista Uningá & 2 & 1.13 \\
\hline & Other journals* & 34 & 19.21 \\
\hline \multirow{22}{*}{ Publication year } & 2015 & 17 & 9.60 \\
\hline & 2010 & 13 & 7.34 \\
\hline & 2014 & 13 & 7.34 \\
\hline & 2018 & 13 & 7.34 \\
\hline & 2019 & 13 & 7.34 \\
\hline & 2016 & 12 & 6.78 \\
\hline & 2020 & 12 & 6.78 \\
\hline & 2011 & 11 & 6.21 \\
\hline & 2017 & 11 & 6.21 \\
\hline & 2012 & 10 & 5.65 \\
\hline & 2009 & 8 & 4.52 \\
\hline & 2005 & 7 & 3.95 \\
\hline & 2013 & 6 & 3.39 \\
\hline & 1999 & 5 & 2.82 \\
\hline & 2004 & 4 & 2.26 \\
\hline & 2007 & 4 & 2.26 \\
\hline & 2008 & 4 & 2.26 \\
\hline & 2003 & 3 & 1.69 \\
\hline & 2006 & 3 & 1.69 \\
\hline & 2001 & 2 & 1.13 \\
\hline & 2002 & 2 & 1.13 \\
\hline & Other years** & 4 & 2.26 \\
\hline
\end{tabular}


Table 1 (continuation)

Results on Journals of the Included Papers

\begin{tabular}{|c|c|c|c|}
\hline Categories & Classification & $\begin{array}{c}\text { Papers } \\
(\mathrm{N})\end{array}$ & $\begin{array}{c}\text { Papers } \\
(\%)\end{array}$ \\
\hline \multirow{2}{*}{ Empirical study } & Yes & 106 & 59.89 \\
\hline & No & 71 & 40.11 \\
\hline \multirow{6}{*}{ Design } & Review and/or theoretical & 67 & 37.85 \\
\hline & Cross-sectional & 67 & 37.85 \\
\hline & Case study & 17 & 9.60 \\
\hline & Case-control & 7 & 3.95 \\
\hline & Cohort & 2 & 1.13 \\
\hline & Other & 17 & 9.60 \\
\hline
\end{tabular}

Note. ${ }^{*}$ Other journals" refers to journals that appeared only once: Arquivos de Neuro-Psiquiatria, Boletim Academia Paulista de Psicologia, Brazilian Homeopathic Journal, Brazilian Journal of Nursing, Brazilian Journal of Rheumatology, Contemporânea - Psicanálise e Transdisciplinaridade, Estudos de Psicanálise, Extensão e Sociedade, Interdisciplinary International Journal - INTERthesis, Journal of Human Growth and Development, Journal of Psychology, Diversity and Health, Journal of School of Nursing - University of São Paulo, Nursing, Psicologia em Revista, Psicologia Hospitalar, Psicologia USP, Psychiatry On Line Brasil, Psychology \& Neuroscience, Reports in Public Helath, Revista Ciência (In) Cena, Revista Contabilidade \& Finanças, Revista de Enfermagem da Universidade Federal de Santa Maria, Revista de Psicologia da IMED, Revista Eletrônica Interdisciplinar, Revista FACID Ciência e Vida, Revista Gaúcha de Enfermagem, Revista Medicina CFM, Revista Neuropsicología Latinoamericana, Revista Perspectivas em Análise do Comportamento, Revista Psicologia em Pesquisa, Revista Saúde e Sociedade, Revista Universo Psi, SMAD Electronic Journal of Mental Health, Alcohol and Drugs, and Transformações em psicologia. ${ }^{* *}$ Other years refers to years that appeared only one time: 1985, 1996, 2000 and 2021. When we could not find the corresponding journal's title in English, the original title was maintained.

Table 2

Methodological Description of Papers Included

\begin{tabular}{|c|c|c|c|}
\hline Categories & Classification on personality & $\mathrm{N}$ & $\%$ \\
\hline & Borderline PD & 81 & 14.34 \\
\hline & Antisocial PD & 66 & 11.68 \\
\hline & Histrionic PD & 31 & 5.49 \\
\hline & Narcissistic PD & 30 & 5.31 \\
\hline & Dependent PD & 29 & 5.13 \\
\hline & Avoidant PD & 28 & 4.96 \\
\hline & Paranoid PD & 27 & 4.78 \\
\hline & Schizotypal PD & 27 & 4.78 \\
\hline & Schizoid PD & 26 & 4.60 \\
\hline & Obsessive-compulsive PD & 18 & 3.19 \\
\hline & Non-specified PD & 15 & 2.65 \\
\hline & Negativistic/Passive-aggressive PD & 11 & 1.95 \\
\hline & Attention seeking & 10 & 1.77 \\
\hline \multirow[t]{14}{*}{ PDs/traits } & Compulsiveness & 10 & 1.77 \\
\hline & Criticism avoidance & 10 & 1.77 \\
\hline & Depressiveness & 10 & 1.77 \\
\hline & Dependency & 10 & 1.77 \\
\hline & Distrust & 10 & 1.77 \\
\hline & Grandiosity & 10 & 1.77 \\
\hline & Impulsiveness & 10 & 1.77 \\
\hline & Conscientiousness & 9 & 1.59 \\
\hline & Isolation & 9 & 1.59 \\
\hline & Mood instability & 9 & 1.59 \\
\hline & Self-sacrifice & 9 & 1.59 \\
\hline & Aggressiveness & 8 & 1.42 \\
\hline & Eccentricity & 8 & 1.42 \\
\hline & Sadistic PD & 8 & 1.42 \\
\hline
\end{tabular}


Table 2 (continuation)

Methodological Description of Papers Included

\begin{tabular}{|c|c|c|c|}
\hline Categories & Classification on personality & $\mathrm{N}$ & $\%$ \\
\hline \multirow{4}{*}{ PDs/traits } & Self-defeating/Masochistic PD & 8 & 1.42 \\
\hline & Neuroticism & 2 & .35 \\
\hline & Psychoticism & 2 & .35 \\
\hline & Other PDs and traits* & 24 & 4.25 \\
\hline \multirow{3}{*}{$\begin{array}{l}\text { Clinical } \\
\text { sample }\end{array}$} & Yes & 50 & 28.25 \\
\hline & No & 56 & 31.64 \\
\hline & None & 71 & 40.11 \\
\hline \multirow{15}{*}{$\begin{array}{l}\text { Assessment } \\
\text { tools }\end{array}$} & Dimensional Clinical Personality Inventory (IDCP) & 21 & 17.07 \\
\hline & Personality Inventory for DSM-5 (PID-5) & 15 & 12.20 \\
\hline & NEO Personality Inventory Revised (NEO-PI-R) & 12 & 9.76 \\
\hline & Dimensional Clinical Personality Inventory 2 (IDCP-2) & 10 & 8.13 \\
\hline & Structured Clinical Interview for DSM-IV Axis II Disorders (SCID II) & 6 & 4.88 \\
\hline & Dimensional Personality Disorders Inventory (IDTP) & 5 & 4.07 \\
\hline & Dimensional Clinical Personality Inventory screening version (IDCP-SV) & 4 & 3.25 \\
\hline & Barratt Impulsiveness Scale (BIS-11) & 3 & 2.44 \\
\hline & Millon Clinical Multiaxial Inventory-III (MCMI-III) & 3 & 2.44 \\
\hline & Structured Clinical Interview for DSM-IV Personality Questionnaire (SCID-PQ-II) & 2 & 1.63 \\
\hline & Self-Reporting Questionnaire (SRQ-20) & 2 & 1.63 \\
\hline & Questionnaire for Borderline personality disorder symptoms evaluation & 2 & 1.63 \\
\hline & The Five-Factor Model Personality Disorder scales (FFM-PD scales) & 2 & 1.63 \\
\hline & Rorschach Test & 2 & 1.63 \\
\hline & Other tests/assessment tools administered ${ }^{* *}$ & 34 & 27.64 \\
\hline \multirow{4}{*}{$\begin{array}{l}\text { Assessment } \\
\text { tools nature }\end{array}$} & Self-report & 106 & 86.18 \\
\hline & Interview & 9 & 7.32 \\
\hline & Projective test & 3 & 2.44 \\
\hline & Other & 5 & 4.07 \\
\hline \multirow{9}{*}{ Focuses } & Psychometric properties studies of PDs/pathological traits measures & 38 & 21.47 \\
\hline & Theoretical and perspectives studies on PDs and PDs traits & 33 & 18.64 \\
\hline & PD review studies & 30 & 16.95 \\
\hline & Theoretical perspectives based on study cases & 17 & 9.60 \\
\hline & Evaluate PD in a specific group of individuals & 12 & 6.78 \\
\hline & Studies associating PD with a mental disorder & 12 & 6.78 \\
\hline & PDs relationship with drugs use studies & 7 & 3.95 \\
\hline & Neuropsychological studies on PDs & 6 & 3.39 \\
\hline & Other*** & 22 & 12.43 \\
\hline
\end{tabular}

Note. ${ }^{*}$ Other PDs or pathological traits that appeared only once: Agreeableness, Antagonism, Audacity, Concern with details, Detachment, Disinhibition, Distortion of moral values, Emotional contagion, Emotional intensity, Empathy, Exceeded control, Instability of behavior, Instability of goals, Instability of self/others, Interpersonal superficiality, Machiavellian Egocentrism, Manipulation, Negative affectivity, Risk behavior, Sadistic aggression, Seduction, Self-directed aggression, Thoroughness and Uncontrolled. ${ }^{* *}$ Names of the Portuguese language instruments were retained when the English language names were not found. Instruments that appeared one time: Adjustment/Neuroticism Factorial Scale (AFS), Agreeableness Factorial Scale (EFS), Checklist according to CID-10, Critérios Diagnósticos para Distúrbio Limítrofe de Personalidade, Entrevista para diagnóstico de transtorno da personalidade borderline - revista (DIB-R), Escala de Esquiva e Desconforto Social (SAD), Extraversion Factorial Scale (EFE), Five Factor Histrionic Inventory (FFHI), IDCP Avoidant Personality Disorder Scale (IDCP-Av), IDCP Histrionic Personality Disorder Scale (IDCP-HPD), IDCP Schizoid Personality Disorder Scale (IDCP-SZPD), Instrumento de Autorrelato para Avaliar Traços de Psicopatia, Inventário Millon de Estilos de Personalidade (MIPS), Iowa Gambling Task Conner's Continuous Performance Test, Iowa Personality Disorder Screen (IPDS), Magical Ideation Scale (MIS), Minnesota Multiphasic Personality Inventory - Hypochondriasis scale, Minnesota Multiphasic Personality Inventory (MMPI), Neuroticism Factorial Scale (NFS), Personality Adjective Check List (PACL), Personality Belief Questionnaire - Short form (PBQ-SF), Personality Disorder Beliefs Questionnaire (PDBQ), Personality Inventory for the DSM-5 - Brief Form (PID-5-BF), Personality Schemas and Beliefs Questionnaire (QECP), Psychopathy Checklist Revised (PCL-R), Questionário de Esquemas de Young - forma reduzida (YSQ-S2), Risk Behavior Scale, Semi-Structured Interview of the Brazilian Research Consortium for Bipolar Disorder, Structured Clinical Interview for Personality Disorders II (SCID II - version 1/9/1989), Taiwan version of the Borderline Personality Inventory - Portuguese (BPI-P), Temperament and Character InventoryReduced (TCI-R) (140), The Massachusetts General Hospital Personality Disorders Checklist (MGH PDC), The Temperament and 
Character Inventory (TCI) and Thematic Apperception Test (TAT). ${ }^{* * *}$ Papers focusing on other specific issues appearing one time: Antisocial PD and Brazilian cinema, Assess traits of psychopathy, empathy and emotional contagion, CEO narcissism and tax avoidance, Emotions and risk behavior, Interventions and related issues for PDs, Investigating applications of the analytical-functional psychotherapy for PDs, Investigating the professional experience of psychotherapists with borderline PD, Maladaptive beliefs and symptoms of Borderline PD, Marital violence dimensions, Nursing care for people with Borderline PD, Pathological traits relationship with career adaptability, Personality traits and engagement with containment measures, Professional interests, Recognition of facial emotions, personality traits and their corresponding personality types, Pathological Personality Indicator (IPP) and engagement at work, Religiosity and the pathological features of PDs, Retrieve HiTOP spectra, Sexual behaviors, Software development, The Pulsatilla nigricans therapeutic effects for narcissistic PD and Verifying the knowledge of nurses on PDs.

Borderline $(n=81 ; 14.34 \%)$ and antisocial $(n=66$; $11.68 \%$ ) were the most recurrent PDs focused in the selected studies. As some papers focused on more than one PD or pathological trait, the total number exceeded the total number of papers.

Nearly $40 \%(n=71)$ of the studies did not involve empirical data collection; studies including data collection were from 1 to 7373 participants $(M=364.41$; $S D=907.26$; Mode $=1$ ). Almost half of these studies $(n=50)$ included clinical samples. In $53.11 \%(n=94)$ of the studies, no assessment tools were administered. In studies where tools were administered $(n=83)$, the sum of all tools was 123 . Two scales were more recurrent in these studies: IDCP $(n=21 ; 17.07 \%)$ and PID-5 $(n=15$; $12.20 \%)$. In agreement with these findings, self-report measures were the most frequent format of the assessment tools reported in the papers.

We observed a large heterogeneity regarding the focus of the papers. Three foci were more usual (see Table 2): "Psychometric properties studies of PDs/pathological traits measures" $(n=38 ; 21.47 \%)$, "Theoretical and perspectives studies on PDs and PDs traits" $(n=33$; $18.64 \%)$ and "PD review studies" ( $n=30 ; 16.95 \%)$. In the first category, we could observe a higher recurrence of papers focusing on the psychometric properties verification of the IDCP in comparison to other scales; papers on Theodore Millon's theory were the most recurrent in the second category; and in the third category, studies about borderline PD were the most frequent. This finding is consistent as one of the IDCP theoretical bases is Millon's theory.

\section{Discussion}

International literature suggests that PDs are undertreated in mental health clinics (Paris, 2015). Previous evidence (Carvalho et al., 2010) indicates that publication focusing on PDs is fewer than other mental health-specific fields in Brazil. To explore what was published on PDs in scientific journals in Brazil, we conducted a narrative review focused on PDs publications in Brazilian scientific journals, synthesizing primary studies and exploring heterogeneity descriptively (Petticrew, \& Roberts, 2006), as well as identifying gaps and presenting suggestions and a research agenda.
Results of our review $(N=177)$ respect less than $15 \%$ of the total records identified. Approximately two-thirds of the papers are presented in the Portuguese language, but in the last eight years, an evident increase in the number of English language publications was observed. These findings indicate that, while the raw number of publications is still local (i.e., only the population with knowledge in the Portuguese language can read), papers published in Brazilian journals focus on science from a global perspective. The increase in the number of papers written in English is followed by an increase in publications in the PDs field. Moreover, we can conclude from the authors' qualifications (masters and doctors), as expected, that most of the studies in the area are conducted by researchers from stricto sensu graduate programs.

Although PDs represent a psychiatric diagnostic classification (APA, 2013), a domain field of psychiatry, the first authors of the selected papers are most from psychological departments in Brazil. However, one must consider that four psychiatric journals account for almost $30 \%$ of the publications. We could not find Brazilian journals specialized in PDs, which is dissimilar from an international perspective (e.g., Journal of Personality Disorders, Personality Disorders: Theory, Research, and Treatment). The leading journals specialized in PD show up in the first quartile for clinical psychology category, according to the Scimago Journal \& Country Rank (SCImago, n.d.), indicating that PD research is among the most read and cited in its broad field (i.e., mental health).

Mirroring the general publication in scientific journals (Cross et al., 2018; Sidone et al., 2016), we observed that two universities from the Southeast region of the country, and specifically from São Paulo State, are responsible for more than $30 \%$ of the publications. This result is in accordance with previous reports showing São Paulo as the Brazilian State with the higher number of publications (Fundação de Amparo à Pesquisa do Estado de São Paulo [FAPESP], 2011).

Approximately $60 \%$ of selected papers were empirical studies, although only $47.17 \%$ of them included clinical samples. $40 \%$ of these studies were restricted to clinical samples composed of people diagnosed with PDs, and $48 \%$ included samples consisting of people with PDs and people from the community. Furthermore, about $40 \%$ of 
publications did not include data collection with human beings. In other words, they focused on reviewing the literature or discussing theoretical perspectives. However, we can observe an increase in the number of empirical studies in the last years. Regarding empirical studies, in the last decade, we can observe that most publications are focused on psychometric properties verification of tools for personality disorders or pathological traits assessment. The Dimensional Clinical Personality Inventory (IDCP; Carvalho, \& Primi, 2015) is the scale with more published studies focusing on psychometric properties, which becomes more evident considering its previous (i.e., IDTP), revised (IDCP-2), and screening (IDCPSV) versions. We can observe only a limited number of publications focused on the other tests. Considering all studies that used tools (i.e., focusing or not on psychometric properties), IDCP versions appear in $34.95 \%$ of publications, followed by the PID-5 (Krueger et al., 2012) and NEO-PI-R (Costa Jr., \& McCrae, 2009). SCID-II was the sole diagnostic tool to appear in more than one publication, even though in less than $5 \%$ of them.

Borderline was the most frequent PD focused in the selected publications, confirming previous literature showing this condition as the most investigated among PDs (APA, 2013; Stanley, \& New, 2018). Antisocial was the second most frequently studied PD in this review. Several traits (e.g., Mood instability, Aggressiveness) were investigated in the publications, but the most frequent appeared only in about $2 \%$ of the studies (Compulsiveness and Depressiveness). Although the two most studies PDs in the selected papers were consistent with previous literature (Skodol, 2010), the most frequent traits seem not to reflect any literature trend.

\section{Conclusions}

We can draw conclusions from this narrative review focusing on mental health professionals and researchers, including a research agenda. As a first recommendation, although SCID-II is usually used as a gold standard for PDs in a global perspective, in Brazil, none of the selected studies investigated its psychometric properties. The diagnostic for PDs is essential in a clinical assessment in mental health (Paris, 2015). However, the tools to be administered must have their psychometric properties verified, preferably in diagnostic accuracy studies (Guthrie, \& Mobley, 1994; Parshall, 2013). Therefore, mental health clinicians in Brazil must be careful when administering the Brazilian version of SCID-II. For pathological traits assessment, IDCP, PID-5, and NEO-PI-R should be the scales of choice, as they present a fair number of studies. However, two reservations on the clinical use: the NEO-PI-R was developed without clinical-driven focus, and we could not find psychometric studies with the Brazilian version of PID-5, only one study with its brief form (PID-5-BF). Complementary, regarding the clinician's update, we recommend searching and reading both psychology and psychiatry journals, including papers written in English.

For mental health researchers, we have specific recommendations and research agenda: (a) studies focusing on psychometric verification, and diagnostic accuracy of clinical tools are required immediately; (b) aiming a global perspective, papers should be written in the English language; (c) studies should include samples from the five regions of the country, and not only focusing on the Southeast region; (d) even though after the present narrative review was conducted one epidemiologic study was published (Santana et al., 2018) focusing one Brazilian city, we recommend future studies to conduct epidemiologic studies not focusing on a specific city as the one that was published; (e) studies testing proposed interventions and/or investigating new interventions are needed; and (f) acknowledged assessment tools for PDs and/or pathological traits assessment (e.g., MMPI2-RF) must be adapted to the Brazilian reality.

Two main limitations of this study must be highlighted. First, this review included studies published on Brazilian scientific journals but not publications in journals from other countries. Second, as we conducted a narrative review, methodological biases are expected. Some of them are not typically observed for systematic reviews (e.g., we did not measure the selected studies' methodological quality). These limitations may restrict the scope of the studies covered in Brazil, therefore reducing the possibility of generalizing our findings. The reader must carefully consider this limitation.

\section{Acknowledgments}

There are no mentions.

\section{Funding}

This research did not receive any funding source, being funded with resources from the authors themselves.

\section{Authors' contributions}

We declare that all authors participated in the preparation of the manuscript. Specifically, the author(s) Lucas de Francisco Carvalho, Gabriel Vitor Acioly Gomes and Ednelson da Silva participated in the initial writing of the study - conceptualization, investigation, visualization, the author(s) Lucas de Francisco Carvalho, Gabriel Vitor Acioly Gomes and Ednelson da Silva participated in the data analysis, and the author(s) Lucas de Francisco Carvalho and Gabriel Vitor Acioly Gomes participated in the final writing of the work - review and editing.

\section{Availability of data and materials}

All data and syntax generated and analyzed during this research will be treated with complete confidentiality due to the requirements of the Ethics Committee for Research 
in Human Beings. However, the dataset and syntax that support the conclusions of this article are available upon reasonable request to the main author of the study.

\section{Competing interests}

The authors declare that there are no conflicts of interest.

\section{References}

American Psychiatric Association [APA] (2013). Diagnostic and Statistical Manual of Mental Disorders, Fifth Edition (DSM-5). American Psychiatric Publishing: Arlington.

Baumeister, R. F., \& Leary, M. R. (1997). Writing narrative literature reviews. Review of General Psychology, 1(3), 311-320. https://doi. org/10.1037/1089-2680.1.3.311

Carvalho, L. F., \& Primi, R. (2015). Development and internal structure investigation of the Dimensional Clinical Personality Inventory. Psicologia: Reflexão e Crítica, 28(2), 322-330. https://doi.org/10.1590/1678-7153.201528212

Carvalho, L. F., Bartholomeu, D., \& Silva, M. C. R. (2010). Instrumentos para Avaliação dos Transtornos da Personalidade no Brasil. Avaliação Psicológica, 9(2), 289-298. http://pepsic.bvsalud.org/scielo.php?script=sci_arttext\&pid=S1677-04712010000200013\&lng=p $\mathrm{t} \& \mathrm{t} \operatorname{lng}=\mathrm{pt}$

Costa Jr., P. T., \& McCrae, R. R. (2009). NEO-PI-R - Inventário de Personalidade NEO Revisado-Manual. Vetor: São Paulo.

Cramer, V., Torgersen, S., \& Kringlen, E. (2006). Personality disorders and quality of life. A population study. Comprehensive Psychiatry, 47(3), 178-184. https://doi.org/10.1016/j.comppsych.2005.06.002

Cross, D., Thomson, S., \& Sibclair, A. (2018). Research in Brazil: A report for CAPES by Clarivate Analytics. Clarivate Analytics: Brazil. http:// www.capes.gov.br/images/stories/download/diversos/17012018-CAPES-InCitesReport-Final.pdf

Dixon-Gordon, K. L., Whalen, D. J., Layden, B. K., \& Chapman, A. L. (2015). A systematic review of personality disorders and health outcomes. Canadian Psychology/Psychologie Canadienne, 56(2), 168-190. https://doi.org/10.1037/cap0000024

Fundação de Amparo à Pesquisa do Estado de São Paulo [FAPESP] (2011). Pesquisadores no Brasil Publicam 56\% dos Artigos Científicos Originados na América Latina. http://www.fapesp.br/indicadores/boletim3.pdf

Gerlach, G., Loeber, S., \& Herpertz, S. (2016). Personality disorders and obesity: A systematic review. Obesity Reviews, 17(8), 691-723. https://doi.org/10.1111/obr.12415

Germans, S., Van Heck, G. L., \& Hodiamont, P. P. (2012). Results of the search for personality disorder screening tools: Clinical implications. The Journal of Clinical Psychiatry, 73(2), 165-173. https://doi.org/10.4088/JCP.11m07067

Gil, A. C. (2008). Métodos e Técnicas de Pesquisa Social. (6 $6^{\mathrm{a}}$ ed.), Atlas: São Paulo.

Guthrie, P. C., \& Mobley, B. D. (1994). A comparison of the differential diagnostic efficiency of three personality disorder inventories. Journal of Clinical Psychology, 50(4), 656-665. https://doi.org/10.1002/1097-4679(199407)50:4<656::AID-JCLP2270500425>3.0.CO;2-V

Huang, Y., Kotov, R., De Girolamo, G., Preti, A., Angermeyer, M., Benjet, C., Demyttenaere, K., de Graaf, R., Gureje, O., Karam, A. N., Lee, S., Lépine, J. P., Matschinger, H., Posada-Villa, J., Suliman, S., Vilagut, G., \& Kessler, R. C. (2009). DSM-IV personality disorders in the WHO World Mental Health Surveys. The British Journal of Psychiatry, 195(1), 46-53. https://doi.org/10.1192/bjp.bp.108.058552

Knipschild, P. (1994). Systematic reviews: Some examples. British Medical Journal, 309(6956), 719-721. https://doi.org/10.1136/ bmj.309.6956.719

Kotov, R., Krueger, R. F., Watson, D., Achenbach, T. M., Althoff, R. R., Bagby, R. M., Brown, T. A., Carpenter, W. T., Caspi, A., Clark, L. A., Eaton, N. R., Forbes, M. K., Forbush, K. T., Goldberg, D., Hasin, D., Hyman, S. E., Ivanova, M. Y., Lynam, D. R., Markon, K., .. . Zimmerman, M. (2017). The Hierarchical Taxonomy of Psychopathology (HiTOP): A dimensional alternative to traditional nosologies. Journal of Abnormal Psychology, 126(4), 454-477. https://doi.org/10.1037/abn0000258

Krueger, R. F., Derringer, J., Markon, K. E., Watson, D., \& Skodol, A. E. (2012). Initial construction of a maladaptive personality trait model and inventory for DSM-5. Psychological Medicine, 42(9), 1879-1890. https://doi.org/10.1017/S0033291711002674

Krysinska, K., Heller, T.S., \& De-Leo, D. (2006) Suicide and deliberate self-harm in personality disorders. Current Opinion in Psychiatry, 19(1), 95-101. https://doi.org/10.1097/01.yco.0000191498.69281.5e

Littell, J. H., Corcoran, J., \& Pillai, V. (2008). Systematic Reviews and Meta-analysis. Oxford University Press: Oxônia.

Marconi, M. A., \& Lakatos, E. M. (2003). Fundamentos de Metodologia Científica. (5 $5^{\mathrm{a}}$ ed.), Atlas: São Paulo.

Moher, D., Liberati, A., Tetzlaff, J., Altman, D. G., \& The PRISMA Group. (2009). Preferred Reporting Items for Systematic Reviews and Meta-Analyses: The PRISMA statement. PLoS Medicine, 6(7), e1000097. https://doi.org/10.1371/journal.pmed.1000097

Moher, D., Shamseer, L., Clarke, M., Ghersi, D., Liberati, A., Petticrew, M., Shekelle, P., Stewart, L. A. \& PRISMA-P Group. (2015). Preferred reporting items for systematic review and meta-analysis protocols (PRISMA-P) 2015 statement. Systematic Reviews, 4(1), 1-9. https://doi.org/10.1186/2046-4053-4-1

Oldham, J. M. (2017). DSM models of personality disorders. Current Opinion in Psychology, 21, 86-88. https://doi.org/10.1016/j. copsyc.2017.09.010

Paris, J. (2015). The Natural History of Personality Disorders: Recovery and Residual Symptoms [Editorial]. The Canadian Journal of Psychiatry, 60(7), 301-302. https://doi.org/10.1177/070674371506000701

Parshall, M. B. (2013). Unpacking the $2 \times 2$ table. Heart \& Lung: The Journal of Acute and Critical Care, 42(3), 221-226. https://doi.org/10.1016/j. hrtlng.2013.01.006

Petticrew, M., \& Roberts, H. (2006). Systematic Reviews in the Social Sciences: A Practical Guide. Blackwell: Oxford.

Samuels, J. (2011). Personality disorders: Epidemiology and public health issues. International Review of Psychiatry, 23(3), 223-233. https://doi. org $/ 10.3109 / 09540261.2011 .588200$

Santana, G. L., Coelho, B. M., Wang, Y-P., Chiavegatto Filho, A. D. P., Viana, M. C., \& Andrade, L. H. (2018). The epidemiology of personality disorders in the Sao Paulo Megacity general population. PLoS ONE, 13(4), e0195581. https://doi.org/10.1371/journal. pone.0195581 
SCImago. (n.d.). SJR - SCImago Journal \& Country Rank [Portal]. http://www.scimagojr.com

Sidone, O. J. G., Haddad, E. A., \& Mena-Chalco, J. P. (2016). A ciência nas regiões brasileiras: Evolução da produção e das redes de colaboração científica. Transinformação, 28(1), 15-32. https://doi.org/10.1590/2318-08892016002800002

Skodol, A. (2010, February 10). Rationale for Proposing Five Specific Personality Types. http://www.dsm5.org/ProposedRevisions/Pages/ RationaleforProposingFiveSpecificPersonalityDisorderTypes.aspx

Skodol, A. E. (2012). Personality Disorders in DSM-5. Annual Review of Clinical Psychology, 8(1), 317-344. https://doi.org/10.1146/annurevclinpsy-032511-143131

Stanley, B., \& New, A. S. (2018). Borderline Personality Disorder. Oxford University Press: New York.

Steel, Z., Marnane, C., Iranpour, C., Chey, T., Jackson, J. W., Patel, V., \& Silove, D. (2014). The global prevalence of common mental disorders: A systematic review and meta-analysis 1980-2013. International Journal of Epidemiology, 43(2), 476-493. https://doi.org/10.1093/ $\mathrm{ije} / \mathrm{dyu} 038$

Wittchen, H. U., Jacobi, F., Rehm, J., Gustavsson, A., Svensson, M., Jönsson, B., Olesen, J., Allgulander, C., Alonso, J., Faravelli, C., Fratiglioni, L., Jennum, P., Lieb, R., Maercker, A., van Os, J., Preisig, M., Salvador-Carulla, L., Simon, R., \& Steinhausen, H.-C. (2011). The size and burden of mental disorders and other disorders of the brain in Europe 2010. European Neuropsychopharmacology, 21(9), 655-679. https://doi.org/10.1016/j.euroneuro.2011.07.018

Yen, S., Shea, T., Pagano, M., Sanislow, C. A., Grilo, C. M., McGlashan, T. H., Skodol, A. E., Bender, D. S., Zanarini, M. C., Gunderson, J. G., \& Morey, L. C. (2003). Axis I and Axis II disorders as predictors of prospective suicide attempts: Findings from the collaborative longitudinal personality disorders study. Journal of Abnormal Psychology, 112(3), 375-381. https://doi.org/10.1037/0021-843X.112.3.375

\section{Sobre os autores}

Lucas de Francisco Carvalho is Psychologist from Universidade Presbiteriana Mackenzie, Master and PhD in Psychology from Universidade São Francisco (USF). Professor at the Psychology department of USF.

Gabriel Vitor Acioly Gomes is Psychologist from Universidade Estadual do Ceará (UECE), Master in Education from Programa de Pós-Graduação em Educação/UECE and PhD in Psychology from Programa de Pós-Graduação em Psicologia da Universidade São Francisco (USF).

Ednelson da Silva is Psychologist from Universidade Federal da Bahia (UFBA) and Master in Theology from Pontificia Universitá Gregoriana (PUG) da Itália.

\section{Como citar este artigo}

Carvalho, L. F., Gomes, G. V. A., \& Silva, E. (2021). Publications on personality disorders in Brazilian journals: a narrative review. Avaliação Psicológica, 20(3), 369-378. http://dx.doi.org/10.15689/ap.2021.2003.17990.11 